\title{
Improving the Life Quality of Low-Income Communities through Hydroponic Bean Sprouts Business
}

\section{Mariati Sinuraya ${ }^{1}$, Diana Sofia Hanafiah ${ }^{2}$, and Hotnida Sinaga ${ }^{3}$}

Faculty of Agriculture, Universitas Sumatera Utara, Padang Bulan Medan 20155

\begin{abstract}
This community service was carried out on 20 persons from various backgrounds with no permanent jobs The purpose is to help people with low incomes to meet their daily needs by creating business opportunities. The target is to improve their living standard within limited space and funds they have. The training used lectures and practices approaches. The results shows that after training, the trainees can produce and sell their hydroponic bean sprouts, thus improving their incomes for about Rp. 300.000 per month.
\end{abstract}

Keywords: PKM, Training, Bean sprout, Hydroponics

\begin{abstract}
Abstrak. Program Kemitraan Masyarakat ini dilaksanakan pada 20 orang peserta yang tidak memiliki pekerjaan tetap di Jl. Pales dan Gang Bilal Medan, mulai bulan Juni sampai November 2019. Tujuan pengabdian pada masyarakat ini untuk menolong masyarakat yang berpenghasilan rendah dalam memenuhi kebutuhan sehari-hari dengan menciptakan peluang usaha. Target yang ingin dicapai adalah meningkatkan taraf hidup mereka, dalam keterbatasan ruang dan dana yang mereka miliki. Metode yang digunakan adalah dengan memberikan ceramah dan pelatihan dengan praktek langsung tentang pembuatan tauge hidroponik. Hasil pengabdian pada masyarakat ini telah berhasil meningkatkatkan penghasilan peserta pelatihan sekitar Rp. 300.000 per bulan.
\end{abstract}

Kata Kunci: PKM, Pelatihan, Tauge, Hidroponik

Received 10 October 2019 | Revised 29 October 2019 | Accepted 12 November 2019

\section{Introduction}

Based on the data of Badan Pusat Statistika Provinsi Sumatera Utara [1], the percentage of poor people in North Sumatra in March 2018 was 9.15\%, decreased by 1.6 thousand compared to September 2018. The poverty rate continues to decrease by 0.11\% points, from 8.94\% in September 2018 to 8.83 percent in March 2019. However,

\footnotetext{
*Corresponding author at: Faculty of Agriculture, Universitas Sumatera Utara, Medan 20155, Sumatera Utara

E-mail address: mariati@usu.ac.id
} 
this is still equal to 1.29 million poor people, puttingNorth Sumatra as the $18^{\text {th }}$ out of 34 provinces in Indonesia [3].

To help the government in reducing the poverty number, the Community Service of Agricultural Faculty, Universitas Sumatera Utara team shared knowledge about hydroponic bean sprouts business with low-income people around Medan City. They have low and uncertain income, low-educated, live in small rented house in slum area around the banks of the Babura river, therefore need to have business opportunity that is easy to be done in a relatively limited space.

Hydroponic bean sprouts are one type of potential vegetables that deserve to be developed intensively on an agribusiness scale and can be cultivated at a household scale because in the process of its production does not require large space, and can be done in the home. Hydroponic bean sprouts also have several advantages sach as, planting does not depend on the season, harvest time is very short, free of pesticides, clean, and has a good enough opportunity to enter supermarkets, restaurants and hotels.

Bean sprouts also have many benefits for human health, containing vitamin $\mathrm{C}$, thiamine, riboflavin, niacin, pantothenic acid, vitamin B6, folate, choline, $\beta$-carotene, vitamin $\mathrm{A}$, vitamin $\mathrm{E}$ ( $\alpha$-tocopherol), vitamin $\mathrm{K}$ and minerals calcium $(\mathrm{Ca})$, iron $(\mathrm{Fe})$, magnesium $(\mathrm{Mg})$, phosphorus $(\mathrm{P})$, potassium $(\mathrm{K})$, sodium $(\mathrm{Na})$, zinc $(\mathrm{Zn})$, copper $(\mathrm{Cu})$, manganese $(\mathrm{Mn})$, and selenium (Se). Essential amino acids contained in bean sprouts include tryptophan, threonine, phenylalanine, methionine, lysine, leucine, isoleucine, and valine [4]; [5]. Consuming bean sprouts is good to prevent a vascular desease [6].

The hydroponic bean sprouts business is the most appropriate and fast solution to overcome the problems of partners, because with this effort the time needed from preparation to harvesting the bean sprouts is only three days. On the fourth day they are able to bring their hydroponic bean sprouts to the market for sale. This hydroponic bean sprouts has a very good prospect to be marketed because based on a survey conducted by The Community Service of Agricultural to traditional markets, bean sprouts sell out very quickly and buyers are often disappointed because they do not find the bean sprouts they are looking for.

The advantages of hydroponic bean sprouts compared to the ordinary one are more practical in manufacturing, easy to dispose its roots, and the selling price is higher. The bean sprouts production activity does not require complicated maintenance, only 
requires maintenance of watering twice a day so that it does not interfere with their activities and the results can really increase their income and the quality of their life.

\section{Methods}

The training implementation methods for overcoming partner problems are as follows:

a. Preparation and Socialization

The preparations made by The Community Service Team with partner Mr. Jepta Sembiring were the preparation of tools and materials needed in training activities and training venues. The program socialization was carried out by the The Community Service Team to all training participants totaling 20 candidates for Hydroponic Bean Sprouts Entrepreneurs

b. Implementation

1. Training and direct practice to produce hydroponic bean sprouts.

2. Training and direct practice to package bean sprouts for sale on the traditional markets, supermarkets and upper middle class consumers. During the training, direct practice and discussion were conducted.

c. Monitoring and Evaluation

Monitoring and evaluation are carried out continuously during the mentoring process both in direct meetings as well as through the WA group of 'Pengusaha Tauge Hidroponik" that have been created by the group leader. Evaluation is carried out to determine the achievement of targets and to determine the next steps.

\section{Results and Discussion}

\subsection{Preparation and socialization}

The first activity carried out by The Community Service Team was to identify the problems by discussing with garbage collectors, cleaning services, doorsmeer employees, traveling traders and some people working odd jobs and unemployed who were assumed to have uncertain income. When The Community Service Team offered them learning how to make hydroponic bean sprouts, which in a very short time could make them into bean sprouts entrepreneurs, they welcomed with enthusiasm. From the results of the identification, Mr. Jepta Sembiring was appointed as the head of the group of "Pengusaha Tauge Hidroponik".

In the socialization, the materials were given about the prospect of hydroponic bean sprouts, the selection of varieties of green beans that are good for bean sprouts, the 
benefits of bean sprouts for human health, technique to make hydroponic sprouts theoretically, and how to reach the consumers.

\subsection{Implementation}

The training was conducted in two locations, namely in Jl. Pales, Simpang Selayang Medan Tuntungan and in Jl. Starban Gang Bilal Ujung, Medan Polonia. Participants attended the first meeting in Jalan Pales that held on Saturday the 24th of August were as many as 14 people and in the Gang Bilal on 2 September as many as 6 people. At this time, each participant was given by The Community Service Team $15 \mathrm{~kg}$ green bean and the complete equipment needed for the production of the hydroponic bean sprouts from preparation to harvest to packaging bean sprouts (Figure 1). The training was practiced directly by The Community Service Team. The enthusiasm was shown by the participants (Figure 2), and active discussions took place during the demonstration.

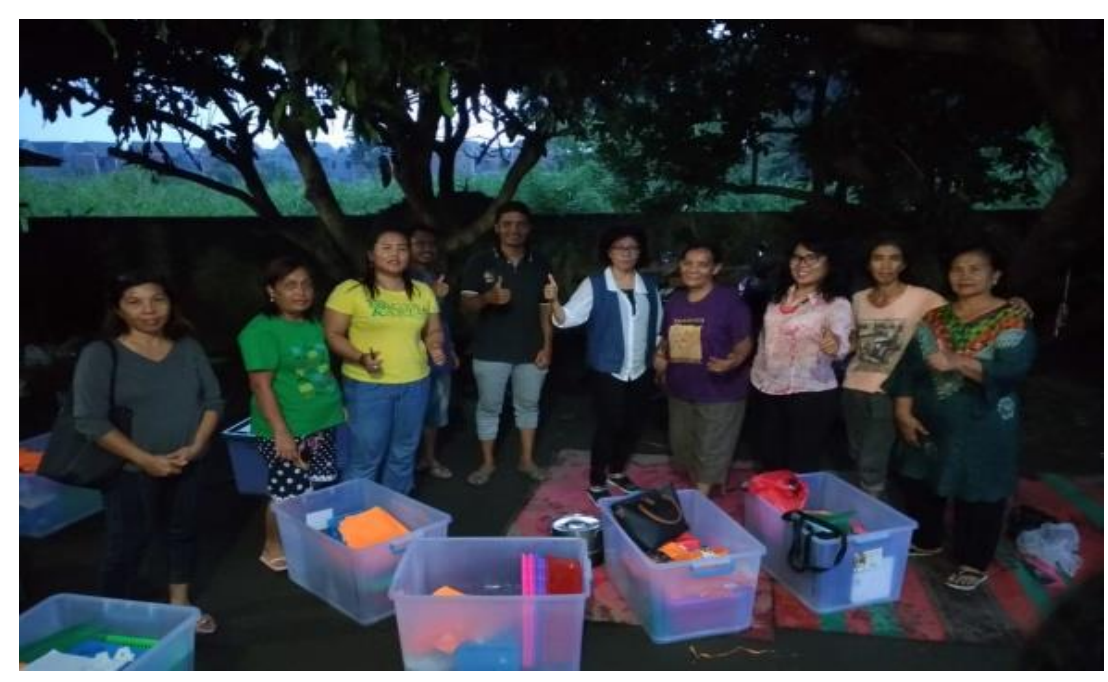

Figure 1. The distribution of materials and equipment for participants

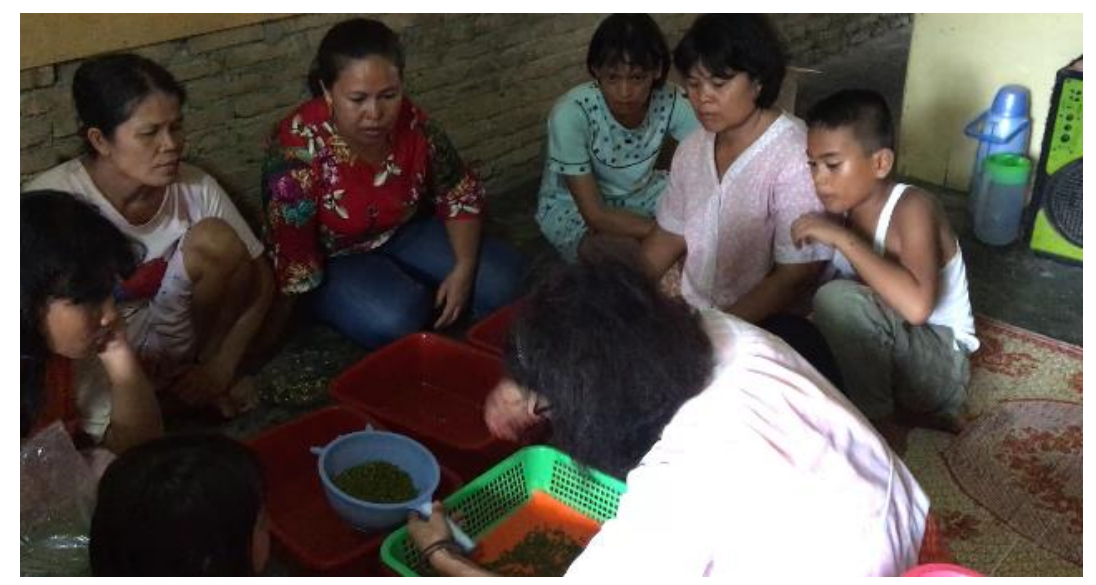

Figure 2. Participants in Gang Bilal, were very enthusiastic to pay attention to the demonstration of making Hydroponic bean sprouts 


\subsection{Monitoring and Evaluation}

Up to now The Community Service Team has provided assistance for about 2 months. On this occasion The Community Service Team shared information about the progress and obstacles faced by participants during making bean sprouts up to the sales process. During the mentoring process, The Community Service Team also conducted monitoring and evaluation both in direct meetings and also through the WA group of "Pengusaha Tauge Hidroponik" that had been made by the group leader.

Each participant must show the bean sprouts that they have practiced in their own homes. So far the results of monitoring have shown that $\pm 85 \%$ of the total participants seriously carried out activities and showed the results they have been achieved.

From the evaluation, The Community Service Team obtained information that most of the participants have started to actively sell their bean sprouts. Some said the selling price is still the same as ordinary bean sprouts or slightly more expensive. This is because the bean sprouts they produce are too thin and long and their marketing still reaches traditional markets. The information received by The Community Service Team is followed up with trying to overcome the problems they encountered by giving them bean sprouts nutrition. The added nutrients produce thicker, shorter bean sprouts. However, consumer demand actually varies, some like thin and long bean sprouts, others like short and fat. Overall, buyers like the bean sprouts they sell because they are cleaner and have no roots. This makes their works in the kitchen easier.
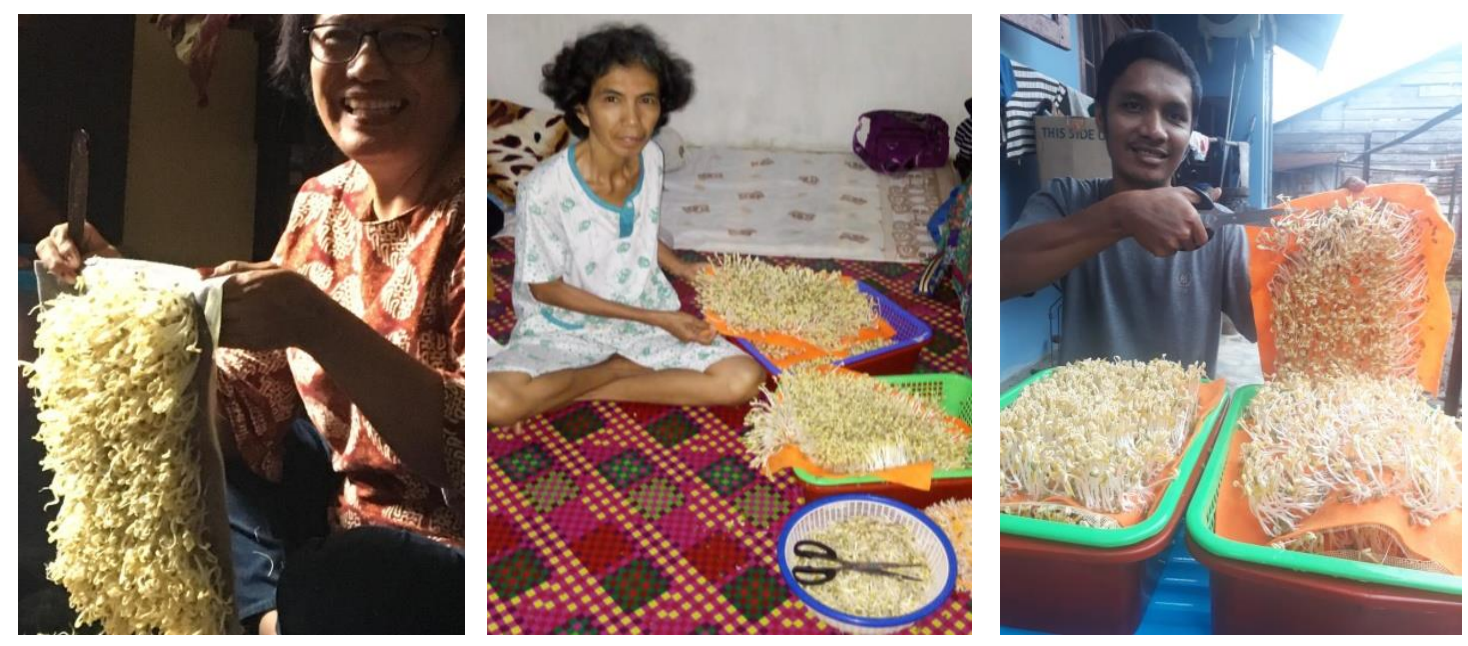

Figur 3. Participants from Jl. Pales from left to right, Dina, Mathilda and Roni, happily showed their bean sprouts

According to the data collected from five active participants, with the bean sprouts business, their average income have increased about Rp. 300.000 per month. If they could increase their 
bean sprouts production every day, their income would be even higher. For now, since the equipment they have is still limited, they only make bean sprouts once every 3 days.
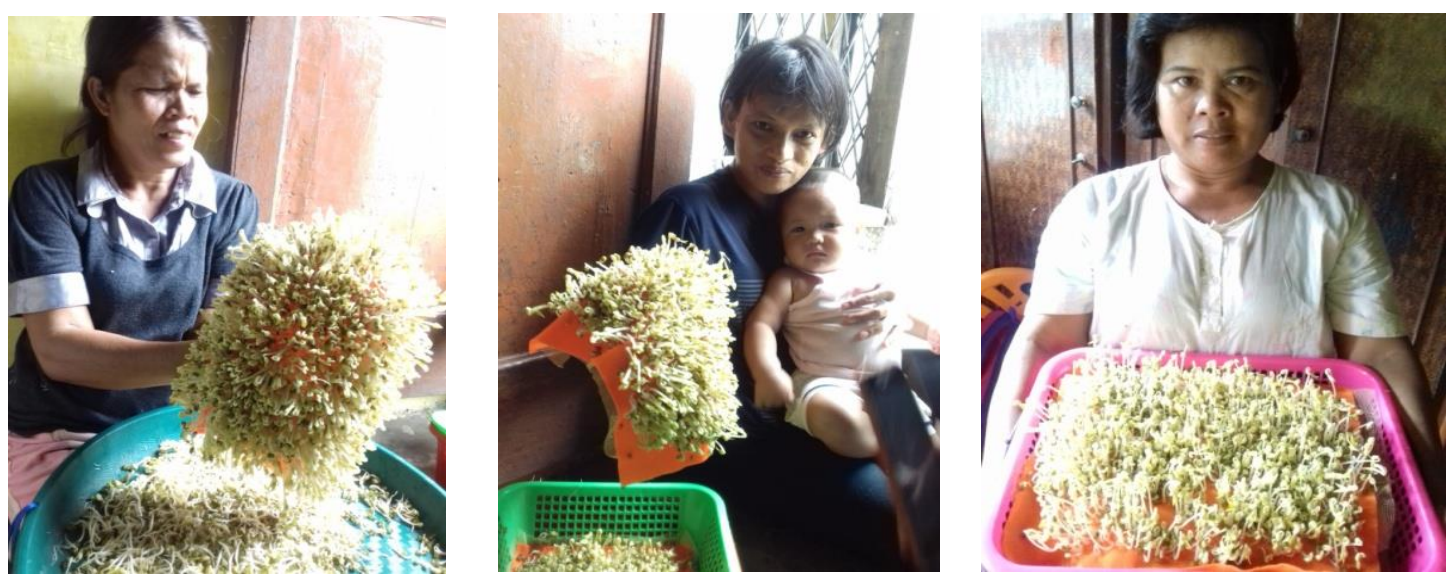

Figur 4. Participants from Gang Bilal from left to right, Rusliana, Sumiati, dan Martina with their bean sprouts

The participants were very enthusiastic about the business, and still enthusiastic about trying to improve the quality and quantity of their bean sprouts productions. They were very grateful for the presence of The Community Service Team from Universitas Sumatera Utara who had taught them how to make hydroponic bean sprouts.

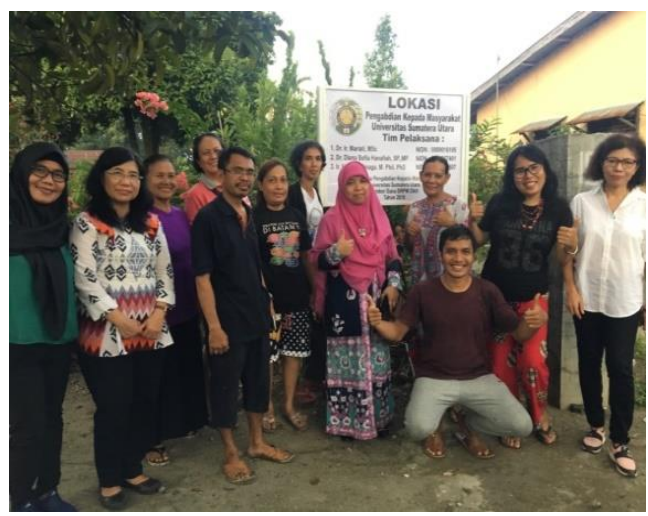

Figur 5. Taking picture with the Internal Monev Team when visiting the service location

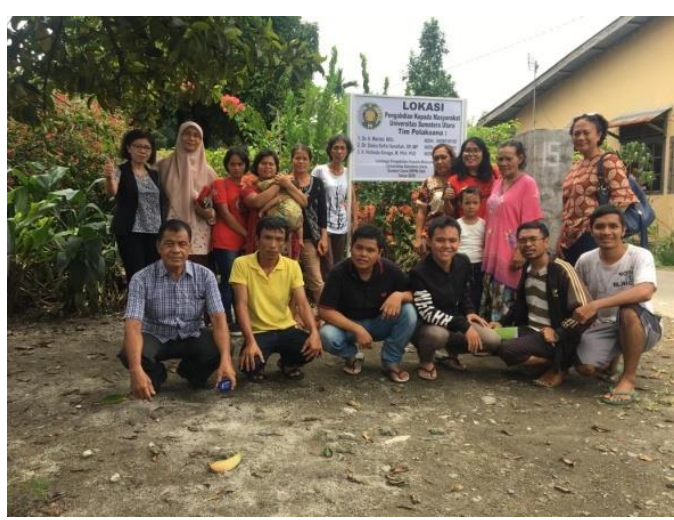

Figur 6. Taking picture The community service Team with participants

\section{Conclusions}

The hydroponic bean sprout training activities conducted by The Community Service Team, Faculty of Agriculture Universitas Sumatera Utara, have succeeded in improving the Life Quality of Low-Income Communities through Hydroponic Bean Sprouts Business, forming a Hydroponic Bean Sprout Entrepreneur group namely "Pengusaha Tauge Hidroponik". Participants who had been unemployed and worked odd jobs have produced and sold their own bean sprouts. The average income of active participants have increased Rp. 300,000.- per month. 


\section{Acknowledgements}

This Community Service was supported by the Grant of Ministry of Research, Technology, and Higher Education (Kemenristek DIKTI), Indonesia through the DRPM service grant program in accordance with the Letter of Agreement for the Implementation of Community Service Grants Number 097/SP2H/PPM/DRPM/2019, March 18, 2019. The Community Service Team respectfully thank Kemenristek DIKTI for providing financial assistance.

\section{References}

[1] Central Bureau of Statistics, Sumatera Utara. 2019. The percentage of poor population in North Sumatra in March 2019 dropped to 8.83 percent. Accessed on: 3 October 2019.

[2] sumatra.bisnis.com. 2019. Penduduk Miskin Sumut capai 1,29 juta orang. http://sumatera.bisnis.com. Accessed on: 2 October 2019.

[3] medan.tribunnews.com. 2019. Penduduk Miskin Sumut Berkurang 33 Ribu Jiwa, Peringkat ke-18 Secara Nasional. Accessed on: 10 September 2019.

[4] Amilah, Astuti, Y. 2006. The Effect of Concentration of Bean Sprout Extract and Green Beans on Vacin and Went Media (VW) on the Growth of Moon Orchid Sprouts (Phalaenopsis amabilis L.). http://www.scribd.com/doc/25831070 /PengaruhKonsentrasiEkstrakTaoge. Accessed on: 8 September 2019.

[5] USDA. 2009. Proteins and Nutrients from Other Beneficial Legumes (Beans): Mung Beans, Mature Reeds, Raw. http://www.nal.usda.gov/fnic/foodcomp/cgi-bin/list_nut_edit.pl. Accessed on: 5 August 2019.

[6] Savage, G.P. 1990. Nutritional value of sprouted mung bean. Nutrition Today, DOI: 10.1097/00017285-199005000-00007. 